\title{
Microorganisms Coexisting Techniques for Waste Treatment
}

\author{
Bhanu Pratap Singh* and Pradeep Srivastava
}

\author{
School of Biochemical Engineering, Indian Institute of Technology (BHU), Varanasi, India
}

*Corresponding author

\section{A B S T R A C T}

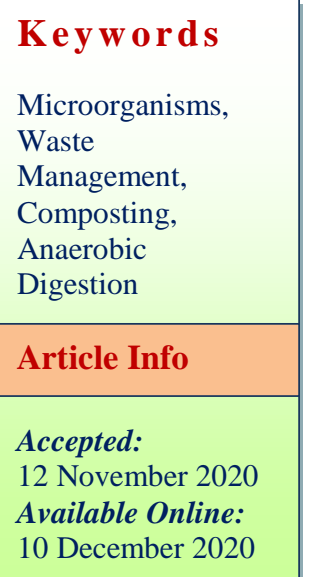

\section{Keywords}

Microorganisms,

Management,

Composting,

Anaerobic

\section{Introduction}

The lessening and reusing of solid wastes has become a standard issue in the current day life of each and every one. Silly waste the board working conditions and plans prompts astounding customary issues, true clinical issues, visual delicateness, destroying smell, etc. and these waste stacks changes into a repeating site for vectors. Pondering nonappearance of guaranteed arranging and financing, the strong waste association condition is winding up being more loathsome a touch immediately. Solid wastes other than achieve Air recoloring, Water ruining and Soil corruption. The current treating the earth approaches were from the most dependable early phase used as a substitute system to invigorate the issues related with waste lessening at the sources and land filling. It is, thusly, essential to make and develop a profitable combination and setting up the earth structure for the verdant kinds of food vegetable wastes that grants procedure of issues accustomed with mix (renouncing smell and sterilization) and plan of basic worth composts.

Senseless strong waste dumps are spreading various contaminations in the assessment 
zone. The critical foundations for the wasteful city strong waste collusion structures are the unintended check of the city, genuine cools, nonappearance of social idea/engineer join, wrong assets including rash mechanical gathering and nonattendance of focal focus interests. A wasteful key strong waste partnership structure may have valid negative standard effects like overpowering ailments, land and water annihilating, tangle of channels and loss of biodiversity.

Urban city solid waste in India are $80-85 \%$ standard being the second most stuffed nation, is on the edge of being the $5^{\text {th }}$ most clear nation on earth. The creating urbanization and making ways of life, food inclinations, and rules brief such exponential improvement of strong waste. It is from a general viewpoint subject for the presentation of a parlor around inertly acclimating different dangers with progress and causing standard miss happenings. Uncontrolled dumping of this waste is a noteworthy achievement concern. All around, there are some relatable events of waste age as we move towards a further advanced society (Fig. 1-6).

\section{Classification of waste}

There might be various sorts of waste, for example, Domestic waste, Factory waste, Waste from oil production line, E-waste, Construction waste, Agricultural waste, Food handling waste, Bio-clinical waste, Nuclear waste, Slaughter house waste etc. Solid waste comprises of all waste materials notwithstanding fluid waste, environmental discharges and dangerous waste. Strong waste is heterogeneous in actual arrangement.

Solid waste- includes waste originated from kitchen, household waste.

Electronic waste- includes discarded instruments such as refrigerator, laptops, speakers and other digital appliances.
Liquid category waste- by industries like leather industries, textile, alcohol production, power plants etc.

Plastic category waste- including daily packaging and item carrying materials, water bottles, buckets etc.

Metal waste-it includes the unutilized metallic sheet and remainings etc.

Nuclear waste- includes unutilized objects derived from the nuclear powerplants

Based on Primary Classification there are 3 types of solid waste as follows:

Solid Wastes based on their Origin

Solid Waste based on their Content Present

Solid Waste based on their Hazardous Potential

\section{Classification on the basis of origin}

Residential - This is made out of wastes produced from structures and lofts, i.e., extra/wasted food, rotten vegetable strips, plastic, garments, wooden objects, metals items, electronic things, glassier remains, and so forth

Municipal - This comprises of wastes produced from road cleaning, finishing, parks, waste treatment plants, managing trees, ooze, and other merrymaking zones.

Industrial - It alludes to wastes from mechanical exercises and comprises of cycle wastes, remains, destruction, and development wastes.

Commercial - This incorporates wastes from stores, eateries, markets, inns, clinical offices, and auto fix shops (extra eatables, glassier, metallic, remains).

Constructional - It alludes to wastes created from constructional exercises such as street fix, destruction of old structures, and development of new structures which incorporate metal, plastic, glass, concrete, rocks, electrical wastes, and so forth 
Agricultural - This alludes to wastes produced from fields, ranches, harvests, dairies, and grape plantations, which incorporate ruined grains, vegetables, farming remaining parts, litter and perilous waste similar to pesticides, and so on

Institutional - It alludes to wastes created from instructive, managerial, and various public structures like the schools, universities, and workplaces, which incorporate paper, glass items, plastic objects and bags, metallic items and scraps, extra food, and so forth

Bio-Medical waste - It alludes to wastes from emergency clinics, clinical shops, research labs, and facilities, which incorporate gloves, swathes, dispensable needles, instruments, synthetic compounds, infected blood, various bodily liquids, clean materials, and infected blood contacted materials.

Mining waste - It alludes to wastes produced from opencast as well as underground type of mining, incorporating inactive materials, for example, debris.

\section{On the basis of content present}

Garbage - These are wastes of creature and plant beginning produced from dealing with, serving, stockpiling, cooking, and so on It contains generally putrescible and effectively decomposable natural issue.

Ash and buildups - This waste classification involves substances staying in the wake of consuming of flammable materials, for example coal, charcoal utilized for cooking as well as warming purposes in residential places, businesses, foundations.

Combustible or non combustible - The Combustible wastes are natural segments of this category that can consume like wood materials like papers, cardboards, elastic, leafs, family unit waste, simple plastic. Non Combustible wastes incorporate glass, toxic metals which are not natural by nature and can't consume.
Bio degradable or non-bio degradable Category of Solid waste, that is natural in nature, can be debased by microbes in a brief timeframe is known as biodegradable, and for instance, paper, food and wood and so on, while waste which can't be debased by microbes is known as non-bio degradable, for example, plastic, metallic components, glass etc.

Bulky waste - This alludes to enormous measured waste from families, for example, tires, electrical apparatuses (cooler, clothes washer, and so on), furniture's made either of plastic or of wood, vehicle parts and trees, its branches, and so on

Street waste - These wastes incorporate paper, soil, cardboard, foodie substance/matter, plastic items in any form, leaves gathered from roads, parks, and walkways. Further we can assemble every one of these kinds of waste into wet waste (Biodegradable) and dry waste (Non Biodegradable).

\section{Biodegradable (also known as wet waste)}

Kitchen waste including food misuse, everything being equal, cooked as well as uncooked, including the eggshells and the bones

Flower and natural product waste including juice strips and the house-plant waste Garden clearing or yard waste comprising of the green or dry leaves

Sanitary wastes

Green waste from vegetables, natural product merchants/shop's

Food and Cafeteria shops Waste and so on
Non biodegradable (also known as dry waste)
Plastics usually of all kinds.
Cardboards, containers.
Containers of numerous types barring those containing dangerous material.


Packaging materials of almost all types.

All kind of Glass.

All kind of Metals.

Rags, elastic.

House clearing (dust etc.)

Powered Burned left (Ashes).

Foils, wrappings and sachets nearly of all

kinds (washed)

Discarded electronic things from workplaces, settlements viz. cartridges, tapes, PC disks, printer accessories and other e-parts.

Discarded apparel, furniture and gear.

\section{On the basis of hazardous potential}

Hazardous - defined as solid waste exhibiting atleast one of the mentioned characteristic property i.e. igniting ability, corrosive nature, freely reactive nature or the toxic nature. These are created from assembling measures, different modern cycles and business items.

Non hazardous - Solid wastes that don't follow mentioned characteristic property i.e. igniting ability, corrosive nature, freely reactive nature or the toxic nature are termed as non hazardous.

Radioactive - waste that is generated from nuclear power reactors, hospitals and research centers, research labs, unfair processing plants etc.

Infection creating - Basically refers to the medical/biochemical wastes that are having the very much potential to transmit any sort (such as viral, bacterial etc.) of diseases, including both human as well as animals infection causing waste and wastes from pathology, research labs and from veterinary services.

\section{Challenges}

In light of broad writing audits, perceptions and conversations in various non-industrial nations Schertenleib and Meyer (1992) recognized five run of the mill issues of SWM.

Inadequate inclusion of the populace to be served

Operational failures of civil Solid waste administrations and the board

Limited use of the formal and casual private area in reusing exercises

Problems concerning the administration of (not industrial) dangerous waste, and

Specific issues identified with conclusive removal of SW.

\section{Microorganism}

Microorganisms have been priceless in discovering answers for a few issues humanity has experienced in keeping up the nature of the climate. They have, for instance, been utilized to beneficial outcome in human and creature wellbeing, hereditary designing, ecological security, and civil and modern waste treatment. Microorganisms have empowered attainable and practical reactions which would have been incomprehensible through substance or actual designing techniques. All the more in this way, microbial advances have effectively been applied to a wide scope of natural issues, particularly waste the board issues. Amori et $a l$, insinuated that high organization of nonbiodegradable wastes from neighborhoods bears ramifications of the necessity for elective waste administration answers for achieving reasonable and ecological amicable framework. Such feasible waste administration plan ought to incorporate the advancement of organic strategies for lessening the biodegradable waste segments and some other techniques for reusing, cremation, pyrolysis and gasification framework could be utilized for decreasing the non-biodegradable waste segments. 
One successful biological scheme that is increasingly being adopted in curtailing the many aesthetic and harmful effects of waste disposal in the environment is the use of microbiological techniques that has little or no adverse effect on the environment. Hence, to elucidate how microorganisms act as agent of waste management, by considering the various roles they play in the environment, waste generation and management, some specific uses of microorganisms in waste management and recent advances in microbiological waste management.

\section{Role of microorganisms}

The exercises of man in his current circumstance include a great deal of synthetic combination during the time spent changing over regular assets in the climate into other advantageous structures for utilization. During the time spent making items, man likewise makes issues of contamination. Accordingly, the most worthy answer for the produced wastes in the climate is with the end goal that will helpfully coordinate them all back into climate. That technique includes utilization of microbes (normally yeast). These microbes or species are coordinated into substrates that yields wanted modern items, for example, bioleaching (bio mining), bio cleanser, bio treatment of mash, bio treatment of wastes (bioremediation), bio filtrations, hydroponics medicines, bio treatment of materials, bio catalysts or enzymes, bio monitoring, etc. Additionally, microorg. are imperative to people and the climate, as they partake in $\mathrm{C}-\mathrm{N}$ cycles, just as satisfying other crucial jobs, for example, reusing other living beings' dead remaining parts and byproducts through deterioration. Microorganisms additionally have a significant role in much higher-request multi cellular creatures as symbionts. Some instances of the use of microorganisms in the climate are talked about as follows:
Sewage treatment: Most of all oxidation associated sewage treatment measures depend on huge scope of microorganisms to oxidize natural constituents which are not managable to sedimentation or buoyancy. Anaerobic microorganisms are additionally used to diminish slop solids delivering methane gas (among different gases) and a sterile mineralized buildup. In consumable water treatment, one strategy, the moderate sand channel, utilizes a complex thick layer made out of a wide scope of microorg. to eliminate both disintegrated as well as particulate matter from crude water.

Soil treatment: As we know Nitrogen (N) cycle, in the soils relies upon the obsession of climatic nitrogen, i.e. accomplished by various Di-azo trophs. On one side this can happen is, in knobs in foundations of vegetables that usually contain harmonious microbes of Rhizobium, Meso-, Sino-, Brady, and Azo- rhizobium genera. These can prepare supplements, minerals in dirt accessible to plants, and can give birth to hormones that spike growth and stimulate plant invulnerable framework and trigger/hose pressure reactions. All in all, a more assorted soil microbiome brings about less plant illnesses and better return.

Energy generation: Microorganisms are utilized in fermentation to create ethanol and in biogas reactors to deliver methane. Scientists are investigating the utilization of green growth to create fluid fills and microscopic organisms to change over different types of Agricultural and metropolitan waste into usable powers. Microorganisms with little limbs similar to wire called the nano wires that digest the Toxic waste (counting PCB's \& compound solvents) to deliver power. One sort specifically, called Shewanella, is a remote ocean microscopic organisms that develops these oxygen-chasing nano wires when set in 
less oxygen. Conditions, Researchers found that when organisms' nano wires are pricked with the Pt electrodes, they can convey an ebb and flow. On the off chance that these capacities can be outfit successfully, they might one be able to day be utilized in sewage treatment plants to at the same time digest waste and force the offices.

Fig.1 Typical examples of waste management options for a community
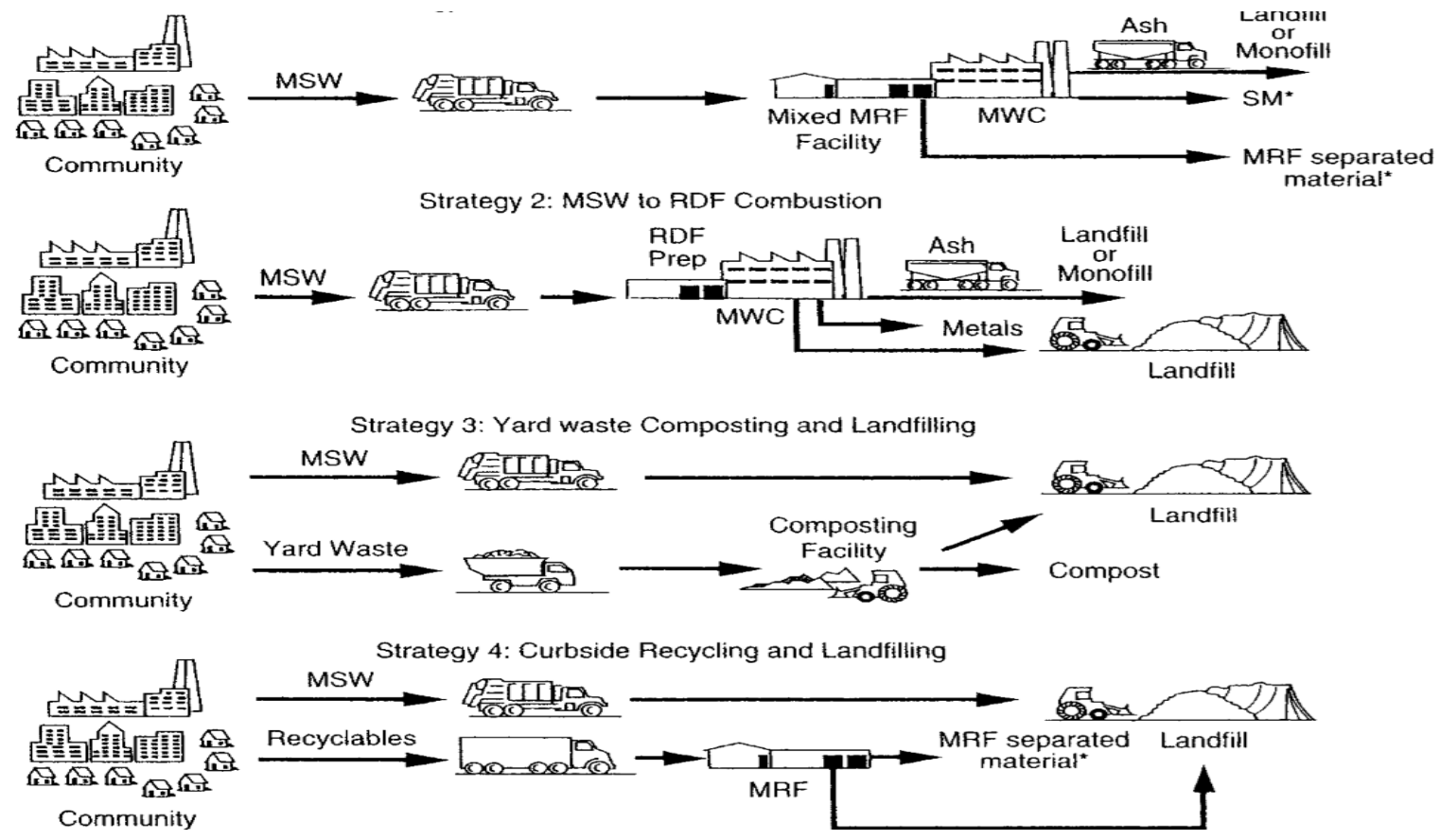

Fig.2 Waste management methods
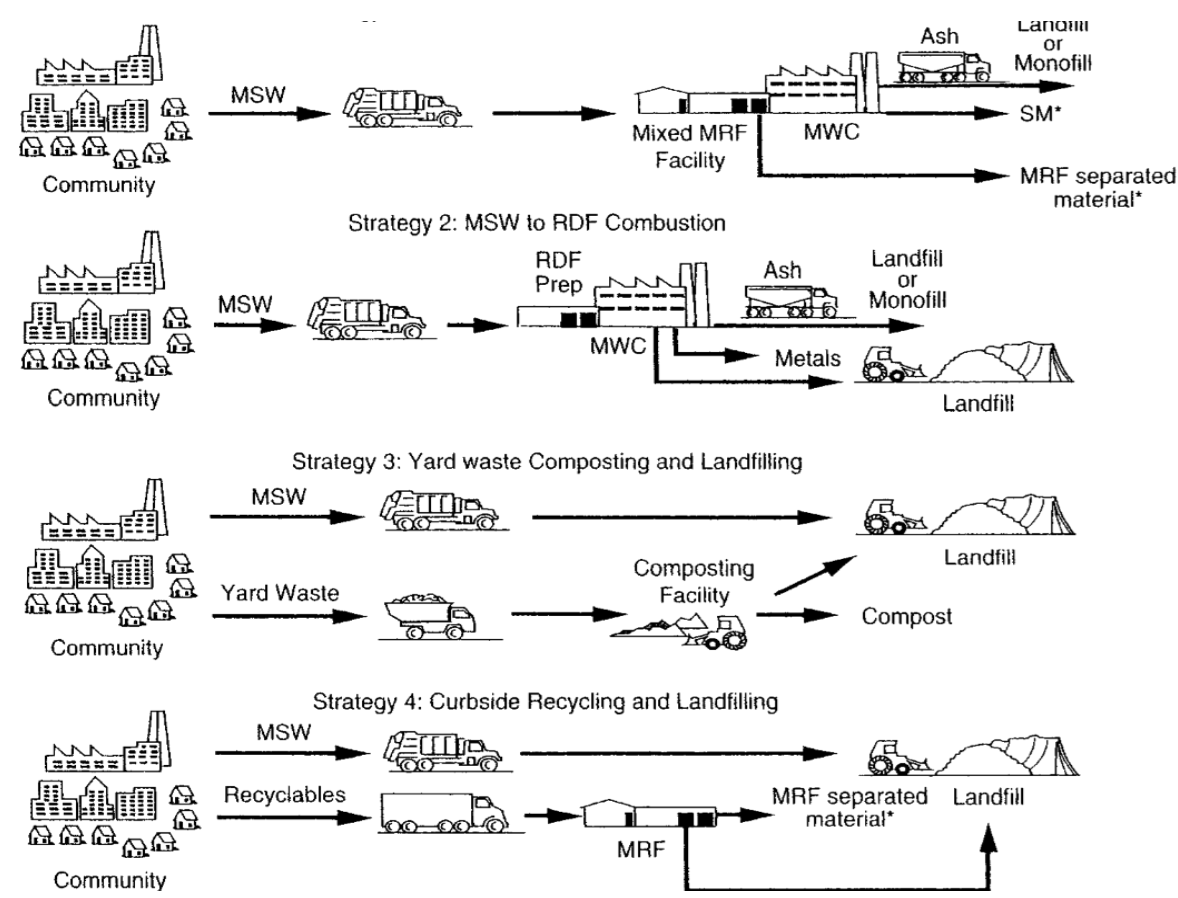
Fig.3 The three main composting systems: a) windrow, b) aerated static pile and c) tunnel or drum (modified from Kumar 2011)

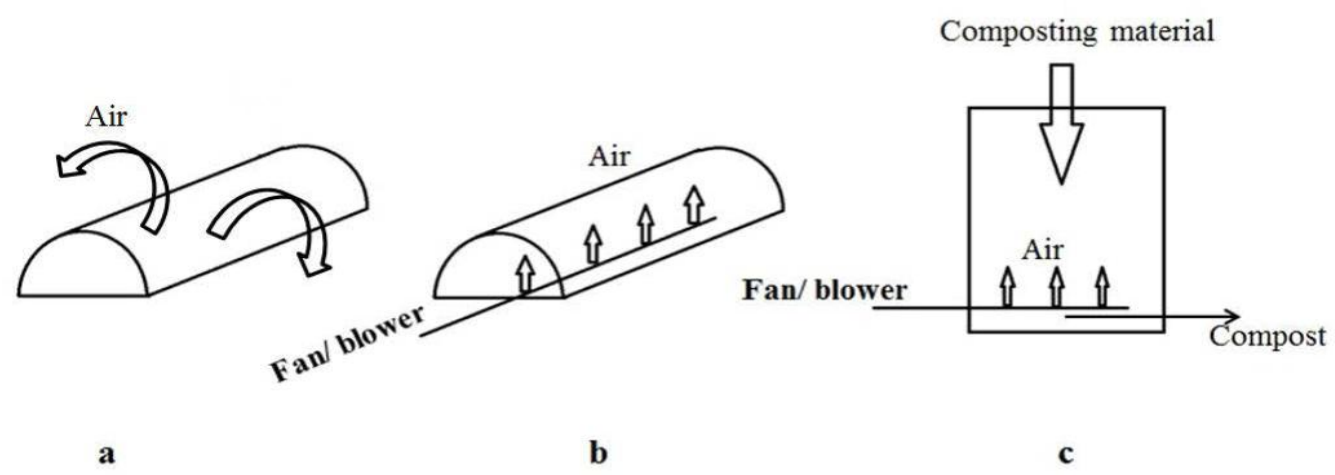

Fig.4 (a) A single-stage and (b) a two-stage continuously stirred tank reactor (CSTR), one of the most frequently used types of anaerobic digestion reactor

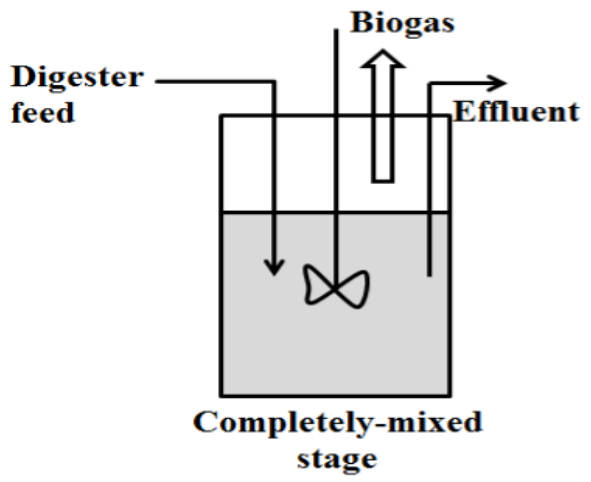

a

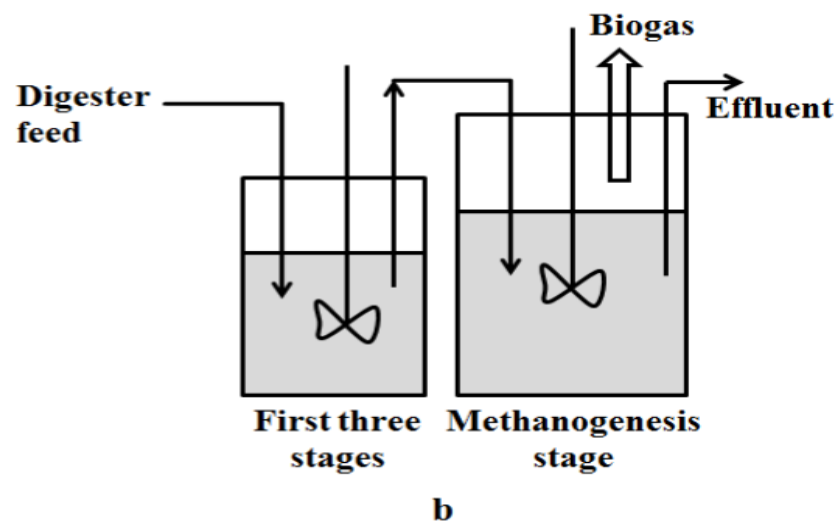

Fig.5 Metabolic pathway of anaerobic digestion: a) hydrolysis, b) acidogenesis, c) acetogenesis and d) methanogenesis

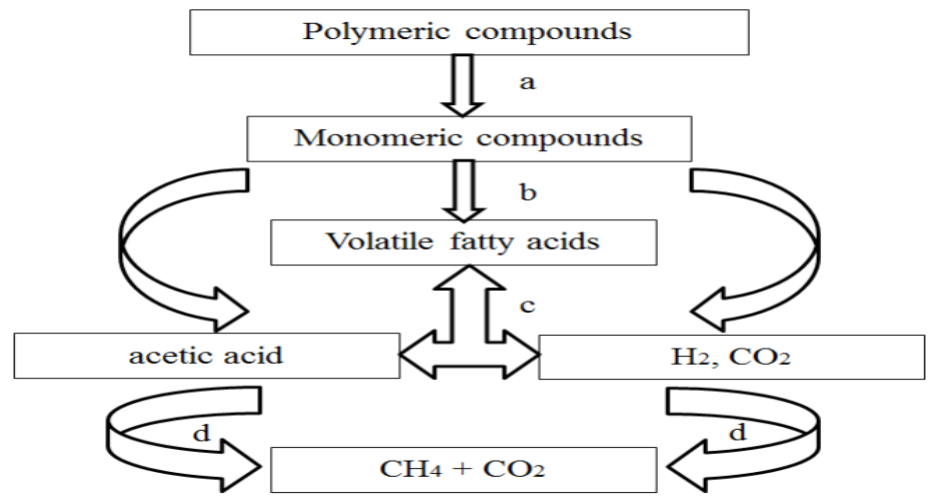


Fig.6 The process of biogas generation from food waste

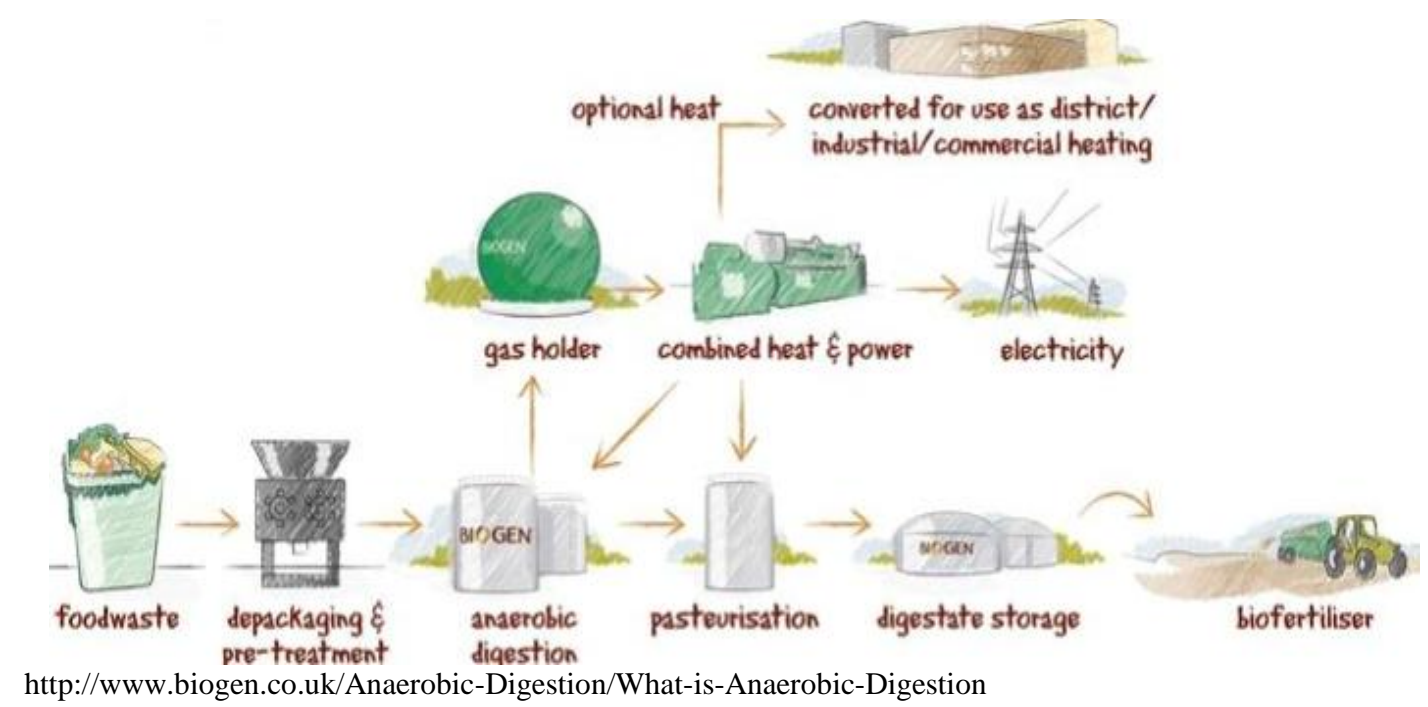

Oil spillage and radioactive contamination

Particular sorts of microbes can tidy up irksome natural toxins like spilled oil. A particular strain, Alcanivorax definitely increments in populace when an oil-slick gives them with quite large sums their supplements, to such an extent that they can eliminate a significant part of oil (example, at Deep-Water Horizontal Spill in Mexican Gulf). Nano wires developed by specific kinds of microbes can likewise be utilized to immobilize destructive materials - like uranium - and shield them from spreading. An examination group at Michigan State University has discovered that Geobacter bacteria, which is found normally in soil, basically electroplates uranium, delivering it insoluble so it can't break down and contaminate groundwater. These microorganisms can be brought into uranium pollution destinations like mines and nuclear plants to contain the radiation, conceivably restricting the tragic results of these kinds of spills.

Waste management methods: Waste the executives is the assortment, transport, preparing or removal, overseeing and checking of waste materials to limit its results on people and climate. Strong waste treatment strategies act to diminish the volume and harmfulness of strong waste, changing it into a more helpful as well as advantageous structure. In Awosusi, waste the board is seen as a cycle of source decrease, deny reusing, controlled burning and controlled landfill; energy age from waste (energy recuperation) and ultimately, strong garbage removal, if the previously mentioned don't offer fitting arrangement. Various cycles are associated with adequately overseeing strong waste. These incorporate observing, assortment, transport, handling, reusing, cremation, landfilling and composting.

This incorporate various kinds of strategies, for example, follows:

Thermal Type Treatment (simply heat to treat the waste materials) likewise the incineration, or gasification \& pyrolysis, and also the open burning;

Dumps \& Landfills like the sanitary landfills and controlled dumps also the bioreactor landfills;

Biological waste treatment such as composting, An-aerobic type digestion. 


\section{Microorganisms used in the management} of waste

The microorganisms which occupy the highimpact natural treatment frameworks incorporate microscopic organisms, parasites, green growth, protozoa and rotifers, and also other higher creatures. Development of any of or a wide range of microorg. in the given modern garbage removal framework will rely on the substance qualities of the mechanical waste, the ecological restrictions of the specific waste framework and the biochemical attributes of the microorganisms. The entirety of the microorganisms which fill in a given modern garbage removal framework add to its general attributes, both great and worst. It's critical, to perceive commitments made by every sort of life form to general adjustment of Organic wastes if waste treatment framework is-to-be appropriately planned \& worked for most extreme productivity.

Bacteria: These serve the fundamental organic units in oxygen consuming wastetreatment frameworks. The assorted biochemical nature of microbes makes it workable for them to process most, if not all, natural mixes found in modern wastes. Commit aerobes. Furthermore, facultative microorganisms are found in all high-impact waste treatment frameworks. Development of specific animal varieties is needy upon its serious capacity to get a portion of the accessible natural material in the system. Bacterial prevalence will typically separate itself into two significant gatherings: the microbes using the organic Compounds in the waste, and the microorganisms using the lysed results of the principal gathering of bacteria.32 the microscopic organisms using the natural mixes in the waste are the main gathering and will decide the attributes of the treatment framework. The species with the quickest developing rate and the capacity to use most of the natural issue will prevail. The degree of auxiliary prevalence will rely on the length of starvation. Depletion of the natural substrate is trailed by death and lysis of the prevail microorganisms. Arrival of the cell parts of the microorganisms grants other microscopic organisms to grow up. Since all natural treatment frameworks are typically overdesigned as a security factor, optional prevalence will happen. Beside the metabolic attributes of the microscopic organisms, the main trademark is their capacity to flocculate. The entirety of the high-impact natural waste treatment systems rely on the flocculation of the microorganisms and their detachment from the fluid stage for complete stabilization. It was first idea that flocculation was brought about by a solitary bacterial animal types, Zoogloea ramigeria, yet ongoing studies have indicated that there are a wide range of microbes which can flocculate. 32 it has been hypothesized that all microscopic organisms can flocculate under certain ecological conditions. The prime variables affecting flocculation are the surface charges of the microorganisms and their energy level. The electrical surface charge on bacteria grown in weaken natural waste frameworks has been demonstrated to be underneath the basic charge for auto-agglutination, 0.020volts. This implies that Brownian development gives adequate energy to defeat the repulsing electrical forces when two microscopic organisms approach one another and to allow the Van der Waal powers of appreciation for prevail and hold the two microorganisms together. Auto agglutination doesn't happen if the energy level of the framework is adequately high to allow the microscopic organisms to increase \& to be quickly motile. Auto agglutination/flocculation, happens simply after microbes come up short on the energy of motility to conquer the Van der Waal powers. Whenever floc has begun to shape, a portion of the microbes bite the dust $\&$ lyse. There an in soluble portion of bacterial cell is separated which is principally 
polysaccharide. More established floc turns into, more poly saccharides develops and less dynamic microorganisms entrained in.

Fungi: It assumes a significant function in the adjustment of natural wastes. Like bacteria, it can process pretty much every sort of natural compounds that are found in modern wastes. They have expected capacity to prevail over microbes however they don't aside from under unordinary natural conditions. Filamentous nature possessed by the greater part of organisms found in mechanical wastes makes them bothersome since they don't shape a congested floc \& settle without any problem. Regarding this last explanation, extensive endeavors are used to make natural conditions better for microorganisms' prevalence than for the organisms with filamentous prevalence. Filamentous fungi prevail over microbes at low oxygen strains, $\mathrm{pH}$ and nitrogen. Lower strain results from lower oxygen flexibly or high natural burden making the interest surpass the gracefully. Under diminished $\mathrm{O}_{2}$ levels, digestion doesn't continue to form carbon di oxide, water however haults with arrangement of natural alcohols, and aldehydes, as well as acids. In the event that the framework needs adequate cushion, the natural acids push down the $\mathrm{pH}$ to the more positive reach for organisms. In this manner, it very well may be seen that low oxygen strain and $\mathrm{pH}$ can be interrelated. A large number of the parasites develop well at the $\mathrm{pH} 4$ - 5 whereas hardly any microbes can develop all around ok to contend. Organisms require very less $\mathrm{N}$ than microbes per unit of cellular material mass. In nitrogen inadequate wastes, parasites can combine more dynamic masses of cellular material from the losses than are the microorganisms and prevail. Microbes normal around 10-12\% N while parasites ranges from $5-6 \%$ nitrogen.

Under ordinary natural conditions parasites will be available and will help in adjustment of natural issue. Yet, the growths are of optional significance and won't prevail.

Algae: The green growth are the third type of natural plants which have an influence in the general adjustment of natural wastes. Since the green growth acquire their energy for union from daylight, they don't need to process the natural mixes like the microorganisms and the parasites. To shape cellular material the green growth principally use the inorganic parts of the wastes, for instance, alkali, $\mathrm{CO}_{2}, \mathrm{P}, \mathrm{Mg}, \mathrm{K}, \mathrm{Fe}, \mathrm{Ca}, \mathrm{SO}_{4}{ }^{-2}$, $\mathrm{Na}$ and different particles. It's conceivable to have green growth and microbes prevail altogether since they don't use similar waste parts. The microorganisms use the natural segments of the waste and delivery a portion of the inorganic parts used by the green growth. During cellular material union the green growth discharge oxygen which is taken by the microbes to achieve total vigorous adjustment of the natural issue. Without daylight the green growth must get the energy needed to remain alive from the digestion of natural issue in similar way as microorganisms and parasites. This natural issue regularly originates from put away food inside the cell yet in few species of algae it can emerge out of natural material in wastes.

Viruses: These are particles collected from biopolymers, competent of increasing and gathering as modern infection particles interior living prokaryotic or eukaryotic cells. Millions are present within the environment and infections are critical for the taking after reasons Pathogenic contaminations must be emptied, Held or demolished in the midst of water and wastewater treatment; Infections of minute life forms (Bacteriophages) can taint and debase the bacterial social orders within the climate; Bacteriophages can also be utilized for recognition of particular microbial tainting of waste within the climate. 
Protozoa: Best creatures found in waste transfer frameworks. Part that protozoans plays in stabilizing natural wastes has as it were as of lately cleared via combining ponder of immaculate culture protozoa (Gram, 1953, unpublished perceptions) with the characteristic perceptions in different organic treatment systems. This consider appeared that instead of being the essential component of filtration, the protozoa were capable for decreasing the number of freeswimming microbes, in this way helping in creating a clarified gushing. The progression of protozoa had long been watched in natural waste transfer frameworks but there was no clarification of the reasons for this progression. The progression of protozoa is influenced by the same components which influence the predomination of any natural species. The sort of nourishment and the competition for nourishment are the major components which decide the predomination of the protozoa.

The Sarcodina are as it were briefly found in high-impact waste treatment frameworks since they don't discover adequate nourishment to compete with the microscopic organisms and other organic shapes. The Phyto-Mastigophora survive a small longer than the Sarcodina as they take in solvent organics for their nourishment but they are incapable to compete against the microbes and are before long uprooted. The ZooMastigophora prevails over the PhytoMastigophora in that they are able to utilize the bacteria for nourishment instead of compete with the microbes for nourishment. But the Zoo-Mastigophora allow way to the free swimming Ciliata which have distant better;a much better;a higher; astronger; an improved component for getting the microbes and other nourishment components. As the framework gets to be more steady, there are less and less free-swimming Ciliata. The lowenergy-requiring stalked Ciliata uproot the high-energy-requiring free-swimming Ciliata. But before long the framework gets to be so steady that the stalked Ciliata cannot get sufficient vitality and kick the bucket out of the system. The progression of protozoa offer good index of stability of the biological waste treatment system.

Endeavors have been made to relate the numbers of protozoa to the degree of stabilization but they have not been fruitful since the same numerical populace exists at two partitioned and particular levels of filtration. Moo numbers of free swimming Ciliata happen at both a moo degree of decontamination, 20 to $40 \%$, and at tall filtration, 75 to $95 \%$. The relative sorts of protozoa and relative numbers can be utilized for any specific framework to gauge the harsh proficiency, $\pm 10 \%$, of any natural treatment system.32 the protozoa have more complex metabolic frameworks than do microscopic organisms or parasites which make the protozoa more touchy to harmful natural compounds.

In frameworks containing harmful natural compounds, customary perceptions of the protozoa can be utilized as an marker of the harmful concentration and to caution of potential harmfulness to the microscopic organisms which are capable for stabilization of the wastes. The protozoa can too be utilized to show lacks of certain basic components such as nitrogen or phosphorus. Supplement lacks will decrease both number of species and number of any specific species. In India, districts created a expansive extent of which was bio-waste. Bio-waste comprises of biodegradable wastes such as cultivate, nourishment and family waste. It primarily comprises nourishment waste and family waste, and regularly encompasses a moo $\mathrm{pH}$ extend. Sewage slime, an insoluble buildup delivered amid wastewater treatment and consequent slime stabilization, is another 
major MSW division (semi-solid; Arthurson, 2008). Sewage slime contains overwhelming metals and ineffectively biodegradable follow natural compounds, as well as possibly pathogenic microorganisms

\section{Treatment of Municipal solid bio-waste}

In processing of bio degradable fractions of MSW, 2 major alternatives that being employed are

Aerobic treatment

Anaerobic treatment.

In city waste treatment offices, the natural division of strong bio-waste is commonly eliminated and balanced out by methods for organic treatment under oxygen consuming or anaerobic conditions. The recyclable materials, for example, paper and plastics, are recuperated quite far.

Aerobic treatment basically involves fertilizing the soil, bioremediation and burning. Treating the soil of strong bio-waste has been generally applied because of its ecosimilarity, simple operational methodology, just as the age of useful results (Kumar et al., 2011).

Bioremediation could be considered as an ideal climate in which microbial biodegradation happens quickly and totally. It is regularly utilized for cleaning soil and water sullied with natural toxins.

Incineration alludes to the ignition of waste materials, bringing about debris buildup and air outflows. The energy item from burning is high-temperature heat, which can be additionally used to create steam and power.

Anaerobic treatment of civil strong bio-waste for the most part includes anaerobic processing and landfill.
Anaerobic assimilation, natural mixes are debased by anaerobic microorganisms, delivering biogases, for example, methane and carbon dioxide. A landfill is a region where waste deposits, for example waste that can't be used for any further reasons for existing, are stored. Inappropriately worked landfill destinations may deliver leachates containing poisonous synthetics that could cause groundwater pollution. Moreover, in landfill locales, microorganisms produce methane through the debasement of waste. This methane by and large escapes to the air and adds to the nursery impact (Di Lonardo et al., 2012; Clemens et al., 2003). In this manner, the utilization of landfill ought to be limited.

Aerobic composting the beginnings of fertilizing the soil can be followed back to antiquated occasions. Treating the soil is an oxygen consuming microbial-driven cycle that changes over strong natural wastes (for example bio-waste, slime, garden waste, green waste, and farming and modern sideeffects) into a naturally steady, sterile, humuslike material that can be securely gotten back to the climate with no further treatment.

Preceding fertilizing the soil, material with a little molecule size and high dampness content, just as low $\mathrm{pH}$ esteems (for example sewage slime and bio-waste), is generally blended in with building operators, for example, Sphagnum peat, wood chips, biochar and reused manures (Kurola et al., 2010; Zhou et al., 2014). The temperature of treating the soil measures range from surrounding levels to top temperatures as high as $80{ }^{\circ} \mathrm{C}$.

The treating the soil cycle can be isolated into two principle stages:

Active stage (comprising of successive mesophilic, thermophilic and cooling steps) 
and Curing stage (then again named the 'development stage').

During the dynamic stage, biodegradable materials are separated, changed and somewhat mineralized in a progression of steps; natural issue gets balanced out as an outcome of the extraordinary microbial action. The restoring stage is described by the transformation of a piece of the settled natural issue into a humus like grid of supplements and natural issue alluded to as 'develop manure'.

Composting can be isolated into

Large scale treating the soil (LSC) and Small-scale treating the soil (SSC).

Lately, the LSC of source-isolated family waste has developed a worldwide scale (for example bio-waste fertilizing the soil everywhere fertilizing the soil plants in the Nordic nations; Sundberg and Jönsson, 2008). Nonetheless, an extensive part of degradable natural waste is treated in SSC, for example, patio fertilizing the soil. Practically speaking, the SSC framework can be isolated into

Hot and

Cold SSC

\section{Contribution}

Most of SSC is 3 directed as cold fertilizing the soil because of the nonstop utilization of new natural material onto the fertilizing the soil heap. Hot SSC is fundamentally the same as LSC, with the significant separation being in the manure quality, for instance the $\mathrm{C}$ : $\mathrm{N}$ proportion and sterilization (Illmer, 2002).

Composting systems and controls: As a rule, there are three principle treating the soil frameworks: the windrow framework, the circulated air through static heap and the passage or drum framework, on the other hand known as 'in vessel treating the soil'. The windrow and circulated air through static treating the soil frameworks can be worked either inside a cooled building or outside. The passage treating the soil framework must be worked inside. In windrow treating the soil, feedstock materials are accumulated in long columns for deterioration. The treating the soil mass is exposed to turning when the temperature arrives at 55-60 ${ }^{\circ} \mathrm{C}$. Windrow treating the soil is generally utilized at the homestead scale and it creates a moderately enormous volume of fertilizer. In the circulated air through static heap framework, the treating the soil feedstock is now and then covered with reused fertilizer or building materials. This assists with decreasing the scent emanation just as to keep away from prolongation of the negative low-pH time frame. It likewise assists with keeping up a high temperature inside the treating the soil heap, just as to build the extents of microbial gatherings (regularly Bacillus and Actinobacteria) that show a well-working fertilizing the soil cycle.

Circulated air through static heap treating the soil is ideal for the deterioration of homogeneous materials, for example, ooze. In the encased passage framework, the basic treating the soil factors, for example, temperature, oxygen, the $\mathrm{C}$ : $\mathrm{N}$ proportion, dampness substance and scent discharge, can be firmly observed all through the fertilizing the soil cycle. The expense of a passage fertilizing the soil framework is moderately high. Along these lines, it is possibly broadly utilized when the fertilizer is needed to be additionally utilized for direct soil applications.

\section{Composting stages and controlling factors}

Composting is generally considered as a fourphase process consisting of

The Mesophilic Phase $\left(25-40{ }^{\circ} \mathrm{C}\right)$, Thermophilic Phase $\left(40-65^{\circ} \mathrm{C}\right)$, 
Cooling Phase (Alternatively Called The '2nd Mesophilic Phase) And

TheMaturation or Curing Phase.

In the underlying mesophilic stage, effectively degradable mixes (for example sugars) are debased by mesophilic microorganisms, regularly lactic corrosive microbes, for example, Lactobacillus and yeasts. The multiplication of these corrosive creating microorganisms causes a further drop in the $\mathrm{pH}$ level, accordingly hindering the development of different organisms. As the temperature rises, thermophilic microorganisms outcompete the mesophilic microbiota by debasing the leftover degradable substances. The disintegration keeps on being fast at this stage, up to temperatures of around $62{ }^{\circ} \mathrm{C}$, while the $\mathrm{pH}$ turns basic. Because of the fatigue of degradable substances, the quantity of thermophilic microorganisms diminishes, while the temperature begins to drop.

At this stage, the mesophilic microorganisms, with the capacity to corrupt troublesome substrates, for example, hemicellulose and cellulose, overwhelm the microbial network. In the last development stage, obstinate mixes (for example lignin-humus buildings) are shaped and get dominating. In this stage, the physio-compound boundaries presently don't change. The manure gets developed and can from that point be used in different applications (Insam et al., 2010; Hultman et al., 2010; de Bertoldi, 2010). The scope of boundaries for controlling the treating the soil cycle relies upon the area and arrangement of treating the soil, just as its size and advancement; nonetheless, the factors can be ordered into six classes: supplements, dampness content, $\mathrm{pH}$ esteems, oxygen stream, temperature and porosity. Concerning the outside windrow framework, the connected boundaries are fairly basic. They incorporate the treating the soil feedstock and its actual structure, the underlying dampness substance and air circulation as far as the recurrence of turning. In correlation, the passage fertilizing the soil framework has more mind boggling controlling factors. The above-depicted $\mathrm{pH}$ esteems and temperatures are among the main components in the treating the soil cycle.

Other factors are described below:

$\mathbf{N}$ dynamics and $\mathbf{C}$ : $\mathbf{N}$ ratio: Nitrogen is one of the critical components in the treating the soil cycle, since it might have important yet additionally hurtful impacts on the cycle. Here, the emphasis is on the hypothetical course of $\mathrm{N}$ elements during the treating the soil cycle, which contains ammonification, nitrification and denitrification, immobilization, and $\mathrm{N}$ discharge through leachates and depleted gases. Ammonification is a mineralization cycle that happens in different treating the soil stages. During the ammonification cycle, proteins are disintegrated, amino gatherings are delaminated, and in the long run ammonium $(\mathrm{NH} 4+)$ and smelling salts (NH3) are shaped under high $\mathrm{pH}$ and temperature conditions. The change from $\mathrm{NH} 4$ + to NO2 - to NO3 -, known as nitrification, is a two-step oxidation measure that is fundamentally done by alkali oxidizing microbes (for example Nitrosomonas) and nitriteoxidising microscopic organisms (for example Nitrobacter). Denitrification is the microbial decrease of $\mathrm{NO} 3$ - through $\mathrm{NO} 2$ - to vaporous items, for example, $\mathrm{N} 2 \mathrm{O}$ and $\mathrm{N} 2$ under oxygen-restricted conditions by facultative anaerobic bacteria. The ideal temperatures for nitrification and denitrification are inside the mesophilic scope of $15-30{ }^{\circ} \mathrm{C}$, with ideal $\mathrm{pH}$ estimations of $6-8.5$, and hence regularly happen in the relieving period of fertilizing the soil. Immobilization changes over inorganic $\mathrm{N}$ mixes (for example $\mathrm{NH} 4+$ ) into natural $\mathrm{N}$ mixes (for example protein). Vaporous $\mathrm{N}$ aggravates framed during 
ammonification and denitrification are mostly delivered through air circulation during treating the soil. Other water-dissolvable $\mathrm{N}$ mixes are delivered through treating the soil leachate (Körner and Stegmann, 2002). The microbial-driven fertilizing the soil cycle is affected by the extents of carbonaceous and nitrogenous materials that are available in the treating the soil feedstock. Microorganisms need carbon for development and nitrogen for protein amalgamation. A high beginning $\mathrm{C}: \mathrm{N}$ proportion makes a moderate beginning the treating the soil cycle, while a low proportion brings about a significant level of alkali discharge (Tuomela et al., 2000; Tiquia and Tam, 2000). A C: $\mathrm{N}$ proportion of around 30 is suggested as the ideal for quick fertilizing the soil of MSW (Kumar, 2011). During effective treating the soil, the $\mathrm{C}: \mathrm{N}$ proportion is relied upon to diminish as a result of the debasement of natural issue and mineralization.

Moisture content, aeration, porosity and particle size: The dampness substance of treating the soil material is ordinarily kept up by watering. This guarantees the exchange of supplements and is along these lines significant in supporting microbial movement during the treating the soil cycle. A dampness substance of between $25-70 \%$ is suggested for treating the soil (Kumar et al., 2011). In any case, dry manures with a low dampness content (beneath 34\%) become colonized by growths and are most likely helpful for certain plant illnesses (for example Pythium shrivel) (Hoitink et al., 1997). Air circulation during treating the soil is normally accomplished by ventilation and gas cooling.

The ventilation has two functions:

To Supply Oxygen

To Remove Excess Heat.

These capacities can be uncoupled by the presentation of gas cooling. In the uncoupled cycle, natural air is added to gracefully oxygen, and the recycled gas is cooled for heat expulsion. A portion of the NH3 produced from the fertilizer is caught in the condensate that structures when recycled gas is cooled. Accordingly, both the off-gas sum and $\mathrm{NH} 3$ discharge to the climate are firmly decreased (Rudrum et al., 2002). It has been accounted for that exorbitant air circulation causes early cooling of the fertilizing the soil mass and quickens the decrease of the dampness content by water dissipation. In this way, air circulation ought to be appropriately applied, contingent upon the fertilizing the soil substrates (Elorrieta et al., 2002). The porosity (then again named the gas-filled pore volume) demonstrates the water holding limit of fertilizing the soil material, which is likewise fundamental in accomplishing great air circulation all through the fertilizing the soil cycle. Concerning windrow treating the soil, an enormous heap size ought to be dodged, as there is a danger of arrangement of anaerobic zones. For material having a little molecule size and high dampness content (for example bio solids, sewage slime), cofertilizing the soil with a building specialist is fundamental (Zhou et al., 2014). To advance the treating the soil cycle, the oxygen and dampness substance of feedstock ought to be kept at least degrees of $10 \%$ and $30 \%$, individually, while the $\mathrm{pH}$ esteem and the underlying $\mathrm{C}$ : $\mathrm{N}$ proportion ought to be kept up inside the scopes of 6.5-8.0 and 25-40, separately (Szmidt, 2002; Kumar et al., 2011; Ekinci et al., 2000; de Guardia et al., 2008; Lu et al., 2009; Cabeza et al., 2013).

Maturity and stability of compost: The terms fertilizer development and manure strength have been utilized interchangeably. There are, in any case, significant contrasts between the implications of these two terms. Manure soundness mirrors the level of disintegration of the natural issue. Manure is viewed as insecure in the event that it contains a high extent of biodegradable issue 
that may support high microbial action, and fertilizer dependability increments as microbial movement diminishes (Tiquia, 2005). Fertilizer steadiness alludes to the degree of the microbial mass action. Hence, it tends to be dictated by the $\mathrm{O} 2$ take-up rate and the $\mathrm{CO} 2$ creation rate (otherwise called 'respiratory action'), or by the warmth delivered because of microbial action, just as by the capacity of the treating the soil material to warm up again once rehydrated (Ceustermans et al., 2010; Cunha Queda et al., 2002). In correlation with manure dependability, fertilizer development is regularly described by germination files, which are estimations of phytotoxicity. Fertilizer development tests can be ordered into physical, substance, plant and microbial action examines. Develop fertilizer is likewise liable to be steady. Nonetheless, stable fertilizer may not generally be enough full grown to be utilized as a development mode for ensuing applications, for example, for developing certain plant species.

Microbes in Composting: Fertilizers contain a huge and exceptionally different microbial network (predominantly microorganisms and parasites), which assumes a vital function in the deterioration of natural issue during the different temperature periods of treating the soil. Toward the start of the treating the soil cycle, mesophilic microbes, commonly from the genera Lactobacillus and Bacillus (Partanen et al., 2010), prevail. Their populaces essentially increment during the beginning stage of fertilizing the soil, as they are fit for debasing the solvent and promptly degradable mixes, for example, sugars, and warmth is created by their metabolic exercises. As the temperature ascends to around $40{ }^{\circ} \mathrm{C}$, thermophilic microorganisms, for example, Actinobacteria, Bacillus, and Thermus assume control over the corruption and become the predominant gatherings in the microbial network.
Actinobacteria and Bacillus have been portrayed as pointers of the well-working treating the soil (Partanen et al., 2010). Actinobacteria, recently archived as Actinomycetes, have been accounted for as a basic gathering in the fertilizing the soil cycle, since they can use a wide scope of carbon sources, for example, cellulose, lignin and proteins (Epstein, 1996). A few types of Actinobacteria are bottle open minded and can stay dynamic at temperatures of up to 60 ${ }^{\circ} \mathrm{C}$. Likewise, they have been discovered to be incapable contenders when supplement levels are high, consequently getting more serious in a low supplement climate (Nakasaki et al., 1985). During the treating the soil cycle, Actinobacteria regularly prevail in the thermophilic and second mesophilic (cooling) stages, and Bacillus are normally distinguished in all phases of fertilizing the soil. Treating the soil is commonly acknowledged as a high-impact microbialdriven cycle. In any case, anaerobic organisms, for example, Bacteroidetes and Clostridia have likewise been distinguished in fertilizing the soil measures (Partanen et al., 2010; Danon et al., 2008). This finding could be clarified by the restrictions in oxygen move from the free air space into the heterogeneous strong particles of the treating the soil mass, making the fertilizing the soil cycle a co-capacity of anaerobic and highimpact measures (Reinhardt, 2002; Smith, 2009). Clostridia, exacting anaerobic microorganisms that are equipped for corrupting mixes, for example, cellulose and starch, prevail all through all phases of the treating the soil cycle. Notwithstanding these astute microorganisms, others, including types of the genera Salmonella and Yersinia, have likewise been distinguished in fertilizer, particularly in bio-waste manure (Partanen et al., 2010).

Most plant and creature pathogenic organisms are mesophilic and are productively killed at 
appropriate treating the soil temperatures; in any case, if the fertilizing the soil cycle doesn't continue ideally and temperatures don't rise unexpectedly, there is a danger that microorganisms will endure. The presence of these microorganisms in the finished result would demonstrate lacking treating the soil, and could consequently represent a likely danger to compost clients (Hogg et al., 2002). The investigation of fertilizing the soil microorganisms has chiefly centered around microscopic organisms, in spite of the fact that growths have been discovered to be the fundamental degraders of lignin and cellulose (Tuomela et al., 2000). Yeasts and molds have been distinguished in the mesophilic stages, while thermophilic parasites having a place with the Pezizomycota, Zygomycota and Ascomycota (for example Penicillium) have been found in the thermophilic stage; Basidiomycota become bountiful in the cooling and restoring periods of treating the soil cycle (Hultman et al., 2010). Thermophilic parasites develop at temperatures of up to $55{ }^{\circ} \mathrm{C}$, and higher temperatures typically repress contagious development (Insam et al., 2010).

Thus, parasites ordinarily assume an insignificant part during the thermophilic stage. One exemption is the treating the soil of substrates that are especially wealthy in cellulose and lignin, in which case organisms stay significant degraders all through the fertilizing the soil cycle. For the most part, in the relieving period of treating the soil, the proportion of organisms to microbes increments because of the upper hand of parasites under helpless substrate accessibility, which means the power of hard to-debase mixes, for example, lignin and humus.

Antibiosis and hyper parasitism: Antibiosis and hyper parasitism, the two of which are types of enmity, contain the organic control systems of infection concealment. Antibiosis alludes to a relationship between two microorganisms where one is hurt 10 or slaughtered by the other through explicit or vague metabolites, for example, the creation of anti-toxins (for example Pseudomonas and Bacillus that produce anti-infection agents to stifle microorganisms). Interestingly, hyper parasitism is a type of direct hostility, where a microorganism (for example Clostridia and Actinobacteria) straightforwardly assaults a pathogenic microorganism and murders it (de Bertoldi, 2010; Mehta et al., 2014).

Rivalry for supplements and space Competition among microorganisms is the most widely recognized type of concealment of 'supplement subordinate' microbes (Diánez et al., 2005). Microbes, for example, Pythium and Phytophthora rival the helpful microflora for supplements and space. Accordingly, a decrease in the seriousness of plant infection can be noticed. Organisms associated with the two previously mentioned biotic components can by and large endure either on dead plant material or on living plant tissues by colonizing and communicating their biocontrol exercises (Pal and McSpadden Gardener, 2006).

\section{Abiotic factors such as heat, moisture, $\mathrm{pH}$ and the $\mathrm{C}: \mathrm{N}$ ratio}

The abiotic factor temperature affects soilborne infection concealment through influencing the manure microbiota. As referenced above, warming or autoclaving manures wipes out their infection suppressive capacity, as useful (just as negative) microorganisms are executed in hightemperature conditions. In this way, the concealment of microorganisms is generally actuated during the later development or restoring periods of treating the soil. Dry fertilizers with a low dampness content (beneath 34\%) presumably become involved 
by parasites and are helpful, for instance, to Pythium infection (credited to the opposition for supplements between comparable organisms). A base dampness substance of $45 \%$ guarantees the strength of microbes over parasites. A high $\mathrm{pH}$ and low $\mathrm{C}$ : $\mathrm{N}$ proportion in the fertilizing the soil feedstock, because of the presence of alkali, will expand the concealment of phytopathogenic specialists, for example, Fusarium, Pythium and Phytophthora (de Bertoldi, 2010).

Applications of compost end products: The fixing of enactment has expanded the utilization of fertilizing the soil in the treatment of organically degradable waste. Nonetheless, if the fertilizing the soil cycle isn't led ideally and fertilizing the soil temperatures neglect to increment to the objective thermophilic level, there is a danger that the manure final result will be juvenile and may contain human and creature microbes just as weed seeds.

In this way, manure must be utilized as an important finished result subsequent to guaranteeing its clean quality (Hogg et al., 2002). There are numerous techniques for investigating the clean nature of the manure final result. By and by, the requirements of a base temperature and time-frame 11 for treating the soil (for example $24 \mathrm{~h}$ at $70{ }^{\circ} \mathrm{C}$ to $7 \mathrm{~d}$ at $55^{\circ} \mathrm{C}$ ) must be carefully followed to limit the danger. Likewise, opposing collaborations may likewise add to hygienization because of the disposal of pathogenic living beings.

\section{Anaerobic digestion}

Anaerobic assimilation is a set up and supportable treatment alternative for debasing the natural issue into biogas methane and carbon dioxide, various follow gases (for example alkali, hydrogen sulfide) and some warmth without oxygen (Kymäläinen et al.,
2012). The utilization of biogas as an elective wellspring of energy has increased expanding consideration as of late. It is a significant resource in the midst of diminishing nonrenewable energy source supplies and worries about ascents in ozone depleting substance fixations, just as a finished result of settled muck that can be utilized as a manure and for soil molding.

Anaerobic processing reactors have usually been worked at

mesophilic $\left(30-40{ }^{\circ} \mathrm{C}\right)$ and

Thermophilic $\left(50-60{ }^{\circ} \mathrm{C}\right)$ temperatures.

A typical organic loading rate (OLR) for fully mixed anaerobic digesters lies between 1 and $5 \mathrm{~kg}$ COD m-3d -1 (Tchobanoglous et al., 2003). The continuously stirred tank reactor (CSTR) - one of the most-used types of anaerobic digestion reactor in full-scale applications - is commonly divided into two configurations:

\section{Single Stage CSTR}

Two-Stage CSTR

In a solitary stage CSTR, every one of the four periods of anaerobic absorption (hydrolysis, acidogenesis, acetogenesis and methanogenesis) occur in a typical climate. A solitary stage CSTR isn't ideal for all individuals from the consortia, and one of the potential reasons could be that the bioavailability of the encased basic supplements isn't adequate to keep up enzymatic preparing by organisms (Kim et al., 2002).

In a two-stage CSTR, the methanogenesis stage is commonly isolated from the other three phases of anaerobic assimilation, which is accounted for to give a higher cycle proficiency and higher energy recuperation, just as more prominent biogas creation 
contrasted with conventional single stage anaerobic processing (Schievano et al., 2012). Lately, most anaerobic absorption reactors have been developed as two-stage setups.

\section{Anaerobic digestion stages and microbes in} anaerobic digestion

There are four stages in anaerobic digestion: hydrolysis, acidogenesis, acetogenesis and methanogenesis. Bacteria are dominant in anaerobic digestion and comprise up to $80 \%$ of the total microbial diversity (Krauseet al., 2008). Bacterial phyla commonly detected include Firmicutes, Proteobacteria, Bacteroidetes, Actinobacteria, Chloroflexi, Nitrospira, Thermotogae, Fusiobacteria, Spirochaetes and Deferribacteres, while archaeal delegates generally have a place with the phylum Euryarchaeota, which incorporates every known methanogen (Insam et al., 2010). Studies have shown that joining diverse natural wastes for anaerobic coassimilation brings about a substrate that is better adjusted and all the more effectively degradable, prompting a huge expansion in biogas creation (Esposito et al., 2012). The potential reasons could be that co-absorption of wastes wealthy in proteins can give the buffering limit and a wide scope of supplements, while co-assimilation of wastes wealthy in carbon balance the $\mathrm{C}: \mathrm{N}$ proportion and lessen the danger of alkali hindrance (Hills and Roberts, 1981; Hashimoto, 1986). Microbial people group in anaerobic coassimilation measures promptly react to changes in substrate organization, the OLR, reactor plan and working temperatures (Tang et al., 2011; Dohrmann et al., 2011; Levén et al., 2007; McHugh et al., 2004). As a rule, higher bacterial and archaeal varieties are found at mesophilic temperatures (Levén et al., 2007; Pycke et al., 2011). Bacterial people group give off an impression of being impressively more different and dynamic than archaeal networks at any temperature
(McHugh et al., 2004; Ritari et al., 2012). Bacterial gatherings are answerable for acetic acid derivation hydrogen and carbon dioxide creation in the initial three phases.

In the last stage, methanogenic archaea produce methane from acetic acid derivation, or on the other hand from hydrogen and carbon dioxide (Griffin et al., 1998; Liu et al., 2004; Bouallagui et al., 2005; Kotsyurbenko, 2005; Lozano et al., 2009; Pycke et al., 2011; Ritari et al., 2012). Hydrolysis, acidogenesis and acetogenesis (Figure 3: stages a, b and c) Hydrolysis, then again named 'depolymerisation', is among the main enzymatic cycles deciding the effectiveness of the anaerobic absorption. In this stage, biopolymers (polysaccharides, lipids, proteins and nucleic acids) are depolymerized and hydrolyzed into monomeric mixes (sugars, amino acids, unsaturated fats). An intricate network of anaerobic hydrolytic microbes and parasites take up the corruption by delivering extracellular hydrolytic chemicals, for example, cellulases and xylanases and mask the perplexing biopolymers into their auxiliary units. Microorganisms and growths associated with this stage comprise of subgroups of Proteobacteria, Bacteroidetes, Actinobacteria, Firmicutes (for example Clostridium and Bacillus) and Neocallimastix (Insam et al., 2010). The hydrolysis step is trailed by the acidogenesis step, otherwise called the aging advance. Here, monomeric mixes are additionally changed over into intermediates, for example, alcohols, short chain unsaturated fats, carbon dioxide and atomic hydrogen. Microscopic organisms are answerable for most of fermentative responses; detailed genera incorporate Lactobacillus and Clostridium. From that point, maturation items are oxidized into acetic acid derivation, formate, hydrogen and carbon dioxide predominantly by acetogenic microscopic organisms (for example Firmicutes). 
Methanogenesis the last phase of the anaerobic absorption of natural issue, wherein methane is at long last produced, and is completed by methanogenic archaea methanogens. It has been indicated that most archaea in anaerobic digesters are methanogenic archaea (Coats et al., 2012). Methyl-coenzyme $\mathrm{M}$ reductase (MCR) is the impetus for the methane-shaping advance in methanogenic archaeal digestion, and the mcrA quality is a utilitarian marker that is available in all methanogens (Friedrich, 2005). Among the five methanogenic archaeal orders

(Methanobacteriales, Methanococcales, Methanomicrobiales, Methanosarcinales and Methanopyrales), just the initial four are discovered to be predominant in anaerobic absorption. Methanogenic people group in anaerobic absorption have been discovered to be fairly steady (Insam et al., 2010).

\section{Advantages and Applications}

\section{Applications of generated biogas and end stabilized sludge}

Anaerobic assimilation is an entrenched and maintainable treatment choice for bio-waste and sewage muck. The biogas created by anaerobic assimilation measures, principally methane, is a substantial substitute for nonrenewable energy sources in a horde of specialized applications, the real application deciding the quality prerequisites of the gas delivered (Bagge et al., 2005; Kymäläinen et al., 2012). It has been accounted for that absorption at thermophilic temperatures brings about a higher natural issue debasement proficiency (Zabranska et al., 2000; Fernandez-Rodríguez et al., 2013), more noteworthy complete biogas creation (McHugh et al., 2004; Levén et al., 2007; Goberna et al., 2010; Siddique et al., 2014) and prevalent feed substrate hygienization
(Zabranska et al., 2000; Bagge et al., 2005; Arthurson 2008).

In the interim, the cycle deposits - the balanced out end muck - can conceivably be utilized as a biofertiliser in agribusiness in the wake of being thoroughly surveyed for quality because of the danger of metals and pathogenic microorganisms (Bagge et al., 2005; Arthurson, 2008; Lozano et al., 2009; Goberna et al., 2010). Notwithstanding, the buildups are frequently treated the soil before additional application (Gallert and Winter, 2002; Molnar and Bartha, 1988).

DNA-based methods for studying the microbial community: It is broadly acknowledged that under $1 \%$ of all microorganisms are noticeable by customary development based methods because of their restricted development conditions (Amann et al., 1995). Since the fast improvement of the polymerase chain response (PCR, Saiki et al, 1985), trailed by cloning and fingerprinting (for example DGGE, T-RFLP) of the enhanced parts and sequencing procedures, the high variety of microorganisms has been exceptional uncovered. The qualities coding for ribosomal RNA (rRNA) have been comprehensively utilized in examining microbial networks. When all is said in done, the prokaryotic $16 \mathrm{~S}$ and $23 \mathrm{~S}$ rRNA qualities are generally applied in concentrates on bacterial and archaeal variety, while the eukaryal $18 \mathrm{~S}$ and $28 \mathrm{~S}$ rRNA qualities, especially the ITS (Internal Transcribed Spacer) areas situated between the $18 \mathrm{~S}$ and 28S rRNA qualities, have been utilized for profiling contagious variety. The previously mentioned rRNA qualities contain both variable and moderated districts, the last of which permits an all inclusive preliminary plan and the ensuing grouping arrangement. As the ITS locale changes long between various species, the PCR amplicon created is somewhere in the range of 500 and 1200 base 
sets in size (Hultman et al., 2010). As most atomic procedures require DNA concentrates to be utilized as a format for PCR intensification and ensuing network examination, the initial step is to remove DNA from target tests. Removed DNA is in this way refined and measured utilizing reagent units (for example Genomic DNA Purification Kit and PicoGreen dsDNA Assay Kit) to eliminate the abundance groundworks, nucleotides, salts and compounds, just as to evaluate dsDNA in arrangement. When top notch DNA has been acquired, it tends to be enhanced by PCR utilizing groundworks that target either the rRNA qualities at various ordered levels from phylum to species, or the utilitarian qualities of interest. At this stage, if convergences of target bunches should be evaluated, a quantitative polymerase chain response (qPCR) is normally utilized. Subsequent to producing PCR amplicons, different atomic methods have been applied in profiling the microbial network preceding sequencing, for example, the cloning approach and DGGE unique mark procedure.

Cloning and denaturing gradient gel electrophoresis (DGGE): The development of clone libraries and sequencing of PCRenhanced parts is a usually utilized methods for evaluating microbial network creation and variety. Regardless of the way that the cloning approach is more costly and tedious than the usually utilized fingerprinting methods, for example, denaturing slope gel electrophoresis (DGGE), grouping investigation of clone libraries gives an unmatched degree of phylogenetic goal because of the generally since quite a while ago read lengths produced by Sanger sequencing (Leigh et al., 2010).

Nonetheless, the size of the microbial network is typically extremely huge to be completely investigated, and it is accordingly hard to appraise the quantity of required sequenced clones to have the option to arrive at the ideal inclusion in the objective examples (Hui, 2010). DGGE is an atomic unique mark strategy for examining microbial network synthesis and variety, which isolates twofold abandoned PCR results of a comparative length however extraordinary grouping creation. Preceding DGGE, a 5'- GC-rich arrangement (30-50 nucleotides, called 'GC clasp') is fused toward the finish of the forward preliminary (Muyzer et al., 1993). Various arrangements of DNA are denatured at various denaturant fixations, bringing about an example of groups, with each band speaking to an alternate bacterial populace present in the network. DGGE examples can be utilized in two elective habits to consider the microbial network composition. Firstly, DGGE gives a quick presentation of the constituents in both a subjective and a semiquantitative route by exhibiting the areas of DNA examples of the objective examples.

On the other hand, a resulting DGGE-PCR can be led. Be that as it may, the DGGE approach additionally has significant restrictions. Right off the bat, it just distinguishes the key microbial species with a high bounty, and mathematically uncommon phylotypes are not by and large recognized. Muyzer et al., (1993) proposed that any objective DNA that is under $1 \%$ of the absolute objective pool is probably not going to be recognized by DGGE. In that capacity, DGGE investigations ought to be considered to demonstrate just the dominating living beings or 'phylotypes' in a network. Besides, a few microbial animal categories may have a similar DGGE design (Costa et al., 2006). To more readily isolate various groupings, DNA cloning innovation can be used.

Whenever successions are acquired utilizing cloning and DGGE approaches and checked for base-call precision, groupings might be contrasted with information bases, for 
example, Genbank, the Ribosomal Database Project (RDP) and EMBL (http://www.ebi.ac.uk/ena/) to decide the ordered affiliations of the source living beings. Bacterial successions have been relegated to the level the phylum, class, request, family, variety or species at grouping comparability cut-off estimations of 80,85 , 90, 92, 94 or 97\%, separately (DeSantis et al., 2007).

In conclusion the microorganisms comprehensive of microorganism and organisms have set up to enliven the corruption way dependent on the past investigations. The utility of microorganism consortium in treating the soil and AD gives a decision answer for waste organization as substance and warm strategies are currently not helpful in time-frame of cost and energy utilization. Co-treating the soil supported by methods for microorganisms manages the cost of the co-advantages of more attractive corruption and limited valorization of nutrients in the manure. An augmentation of biogas feasible going from $3.9 \%$ to $96.63 \%$ is conceivable with the product of microorganisms for crop deposits in the $\mathrm{AD}$ framework. Despite the fact that the incorporation of microbial should improve the general presentation of fertilizing the soil and $\mathrm{AD}$, the financial practicality of microbial subculture value remains the main issue in future investigations.

\section{References}

Abdel-Hafez, A. I. I., S. I. I. Abdel-Hafez, S. M. Mohawed, and A. H. M. El-Said, "Composition, occurrence and cellulolytic activities of fungi in habiting soils along Idfu-Marsa Alam road at Eastern desert, Egypt," A Bulletin of the Faculty of Science, vol. 20, pp. 21-48, 1991.

Abdel-Hafez, A. I. I., S. I. I. Abdel-Hafez, S.
M. Mohawed, and T. A. M. Ahmed, "Seasonal fluctuations of soil and air borne fungi at Qena, Upper Egypt," A Bulletin of the Faculty of Science, vol. 19, pp. 47-63, 1990.

Abdel-Hafez, S. I. I., A. H.M. El-Said, and Y. A. M. H. Gherabawy "Mycoflora of leaf surface, stem, bagasse and juice of adult sugarcane (Saccharum officinarum L.) plant and cellulolytic ability in Egypt," A Bulletin of the Faculty of Science, vol. 24, pp. 113130, 1995.

Abrha, B. and B. A. Gashe, "Cellulase production and activity in a species of Cladosporium," World Journal of Microbiology \& Biotechnology, vol. 8, no. 2, pp. 164-166, 1992.

Adelana O. Life of scavengers inside Abuja's biggest dumpsite. 2016. Available from URL: https://www.naij.com/780541feature-insidea buja-dump-sitescavengers-make-n637-500month.html

Aelterman, P., Rabaey, K., Clauwaert, P., Verstraete, W., 2006a. Microbial fuel cells for wastewater treatment. Water Sci. Technol. 54 (8), 9e15.

Aelterman, P., Rabaey, K., Pham, H.T., Boon, N., Verstraete, W., 2006b. Continuous electricity generation at high voltages and currents using stacked microbial fuel cells. Environ. Sci. Technol. 40 (10), 3388e3394.

Ahn, Y., Logan, B.E., 2010. Effectiveness of domestic wastewater treatment using microbial fuel cells at ambient and mesophilic temperatures. Bioresour. Technol. 101 (2), 469e475.

Ahn, Y.H., 2006. Sustainable nitrogen elimination biotechnologies: a review. Process Biochemistry 41 (8), $1709 \mathrm{e} 1721$.

Aldrovandi, A., Marsili, E., Stante, L., Paganin, P., Tabacchioni, S., Giordano, A., 2009. Sustainable power production 
in a membrane-less and mediator-less synthetic wastewater microbial fuel cell. Bioresour. Technol. 100 (13), $3252 \mathrm{e} 3260$.

AWWA Research Foundation, California Energy commission (CEC), New York State Energy Research and Development Authority, 2007. Energy Index Development for Benchmarking Water and Wastewater Utilities. AWWARF, Denver, CO.

Ayyaru, S., Dharmalingam, S., 2011. Development of MFC using sulfonated polyether ether ketone (SPEEK) membrane for electricity generation from waste water. Bioresour. Technol. 102 (24), 11167e11171.

Barea JM, Pozo M, Azcón R and AzcónAguilar C. "Microbial co-operation in the rhizosphere". J Exp Bot. 2005, 56 (417): 1761-78. Available from URL: https://academic.oup.com/jxb/articlelookup/doi/10.1093/jxb/eri197.

Barnett, J. L.and B. B. Hunter, Illustrated Genera of Imperfect Fungi, Burgess Publishing Company, Minneapolis, Minn, USA, 1972.

Bassam, H., Mashat. 2014. Effective Microorganisms (EM) Technology As A Pathway To Improve Municipal Solid Waste Of Makkah City (Saudi Arabia) And As Foul Odor Eliminator. The Clute Institute International Academic Conference in Munich, Germany: 80-84.

Berlin, A., N. Gilkes, D. Kilburn et al., "Evaluation of novel fungal cellulase preparations for ability to hydrolyze softwood substrates-Evidence for the role of accessory enzymes," Enzyme and Microbial Technology, vol. 37, no. 2, pp. 175-184, 2005.

Biffinger, J.C., Byrd, J.N., Dudley, B.L., Ringeisen, B.R., 2008. Oxygen exposure promotes fuel diversity for Shewanella oneidensis microbial fuel cells. Biosens. Bioelectron. 23 (6), $820 \mathrm{e} 826$.

Borole, A.P., Hamilton, C.Y., 2010. Energy production from food industry wastewaters using bioelectrochemical cells. In: Emerging Environmental Technologies, vol. II. Springer Netherlands, pp. 97e113.

Brown, J. A., S. A. Collin, and T. M. Wood, "Development of a medium for high cellulase, xylanase and $\beta$-glucosidase production by a mutant strain (NTG III/6) of the cellulolytic fungus Penicillium pinophilum," Enzyme and Microbial Technology, vol. 9, no. 6, pp. 355-360, 1987.

Burton, F.L., 1996. Water and Wastewater Industries: Characteristics and Energy Management Opportunities. Burton Engineering, Los Altos, CA, p. ES-1. Report CR-106941. Electric Power Research Institute Report.

Catal, T., Bermek, H., Liu, H., 2009. Removal of selenite from wastewater using microbial fuel cells. Biotechnol. Lett. 31 (8), 1211e1216.

Cercado-Quezada, B., Delia, M.L., Bergel, A., 2010. Testing various food-industry wastes for electricity production in microbial fuel cell. Bioresour. Technol. 101 (8), 2748e2754.

Chae, K.J., Choi, M.J., Lee, J.W., Kim, K.Y., Kim, I.S., 2009. Effect of different substrates on the performance, bacterial diversity, and bacterial viability in microbial fuel cells. Bioresour. Technol. 100 (14), 3518e3525.

Cheng, S., Dempsey, B.A., Logan, B.E., 2007. Electricity generation from synthetic

Cheng, S., Jang, J.H., Dempsey, B.A., Logan, B.E., 2011. Efficient recovery of nanosized iron oxide particles from synthetic acid-mine drainage (AMD) water using fuel cell technologies. Water Res. 45 (1), 303e307. 
Dai, J., Wang, J.J., Chow, A.T., Conner, W.H., 2015. Electrical energy production from forest detritus in a forested wetland using microbial fuel cells. GCB Bioenergy 7 (2), 244e252.

De Schamphelaire, L., Verstraete, W., 2009. Revival of the biological sunlighttobiogas energy conversion system. Biotechnol. Bioeng. 103, 296e304.

del Campo, A.G., Ca nizares, P., Rodrigo, M.A., Fern_andez, F.J., Lobato, J., 2013. Microbial fuel cell with an algaeassisted cathode: a preliminary assessment. J. Power Sources 242, $638 \mathrm{e} 645$.

Deschamps, F. C., C. Giuliano, M. Asther, M. C. Huet, and S. Roussos, "Cellulase production by Trichoderma harzianum in static and mixed solid state fermentation reactors under nonaseptic conditions," Biotechnology and Bioengineering, vol. 27, no. 9, pp. 1385-1388, 1985.

Desloover, J., Arends, J.A., Hennebel, T., Rabaey, K., 2012. Operational and technical considerations for microbial electrosynthesis. Biochem. Soc. Trans. 40 (6), 1233.

Dong, Y., Qu, Y., He, W., Du, Y., Liu, J., Han, X., Feng, Y., 2015. A 90-liter stackable baffled microbial fuel cell for brewery wastewater treatment based on energy self-sufficient mode. Bioresour. Technol. 195, 66e72.DTI, 2005. Regional Electricity Consumption Statistics, UK.

Du, Z., Li, H., Gu, T., 2007. A state of the art review on microbial fuel cells: a promising technology for wastewater treatment and bioenergy. Biotechnol. Adv. $25 \quad$ (5), $\quad 464 \mathrm{e} 482$. http://www.eia.gov/tools/faqs/faq.cfm? $\mathrm{id}^{1} / 474 \& \mathrm{t}^{1} / 411$ (accessed online)

Duncan, S. M., R. L. Farrell, J. M. Thwaites et al., "Endoglucanase- producing fungi isolated from Cape Evans historic expedition hut on Ross Island, Antartica," Environmental

Microbiology, vol. 8, no. 7, pp. 12121219, 2006.

Elango, R. and J. Divakaran, "Microbial consortium for effective composting of coffee pulp waste by enzymatic activities," Global Journal of Environmental Research, vol. 3, no. 2, pp. 92- 95, 2009.

Ellis, M. B., Demataceous Hyphomycetes, Commonwealth Mycological Institute, Kew, UK, 1971.

Ellis, M. B., Demataceous Hyphomycetes, Commonwealth Mycological Institute, Kew, UK, 1976

El-Said, A. H. M., "Phyllosphere and phylloplane fungi of banana cultivated in Upper Egypt and their cellulolytic ability," Mycobiology, vol. 29, pp. 210-217, 2001.

Etter, B., Tilley, E., Khadka, R., Udert, K.M., 2011. Low-cost struvite production using source-separated urine in Nepal. Water Res. 45 (2), 852e862.

Ewing, T., Babauta, J.T., Atci, E., Tang, N., Orellana, J., Heo, D., Beyenal, H., 2014. Selfpowered wastewater treatment for the enhanced operation of a facultative lagoon. J. Power Sources $269,284 \mathrm{e} 292$.

Ezekiel, C. N., A. C. Odebode, R. O. Omenka, and F. A. Adesioye, "Growth response and comparative cellulase induction in soil fungi grown on different cellulose media," Acta SATECH, vol. 3, no. 2, pp. 52-59, 2010.

Fan, Y., Han, S.K., Liu, H., 2012. Improved performance of CEA microbial fuel cells with increased reactor size. Energy Environ. Sci. 5 (8), 8273e8280.

Fangzhou, D., Zhenglong, L., Shaoqiang, Y., Beizhen, X., Hong, L., 2011. Electricity generation directly using human feces wastewater for life 
support system. Acta Astronaut. 68 (9), $1537 \mathrm{e} 1547$.

Feng, Y., Wang, X., Logan, B.E., Lee, H., 2008. Brewery wastewater treatment using air-cathode microbial fuel cells. Appl. Microbiol. Biotechnol. 78 (5), $873 \mathrm{e} 880$.

Fischer, F., Bastian, C., Happe, M., Mabillard, E., Schmidt, N., 2011. Microbial fuel cell enables phosphate recovery from digested sewage sludge as struvite. Bioresour. Technol. 102 (10), 5824e5830.

Foley, J.M., Rozendal, R.A., Hertle, C.K., Lant, P.A., Rabaey, K., 2010. Life cycle assessment of high-rate anaerobic treatment, microbial fuel cells, and microbial electrolysis cells. Environ. Sci. Technol. 44 (9), 3629e3637.

Fuchs, W., Binder, H., Mavrias, G., Braun, R., 2003. Anaerobic treatment of wastewater with high organic content using a stirred tank reactor coupled with a membrane filtration unit. Water Res. 37 (4), 902e908.

Gadhamshetty, V., Belanger, D., Gardiner, C.J., Cummings, A., Hynes, A., 2013. Evaluation of Laminaria-based microbial fuel cells (LbMs) for electricity production. Bioresour. Technol. 127, 378e385.

Gallo $M$ and Ventresca S. The Role of Microorganisms in the Ecosystem. American Society for Microbiology Education Department. 2016.

Gautam, S. P., P. S. Bundela, A. K. Pandey, Jamaluddin, M. K. Awasthi, and S. Sarsaiya, "Cellulase production by Pseudomonas sp. isolated from municipal solid waste compost," International Journal of Academic Research, vol. 2, no. 6, pp. 330-333, 2010.

Gautam, S. P., P. S. Bundela, A. K. Pandey, M. K. Awasthi, and S. Sarsaiya, "Screening of cellulolytic fungi for management of municipal solid waste," Journal of Applied Science for Environmental Sanitation, vol. 5, no. 4, pp. 367-371, 2010.

Gautam, S. P., P. S. Bundela, A. K. Pandey, M. K. Awasthi, and S. Sarsaiya, "Effect of different carbon sources on production of Cellulases by Aspergillus niger," Journal of Applied Science Environmental Sanitation, vol. 5, no. 3, pp. 277-281, 2010.

Gautam, S. P., P. S. Bundela, A. K. Pandey, M. K. Awasthi, and S. Sarsaiya, "Prevalence of fungi in Municipal solid waste of Jabalpur city (M.P.)," Journal of Basic \& Applied Mycology, vol. 8, no. 1-2, pp. 80-81, 2009.

Goodfellow, M. and S. T. Williams, Bergey's Manual of Systematic Bacteriology, vol. 4, 1989

Goud, R.K., Babu, P.S., Mohan, S.V., 2011. Canteen based composite food waste as potential anodic fuel for bioelectricity generation in single chambered microbial fuel cell (MFC): bioelectrochemical evaluation under increasing substrate loading condition. Int. J. Hydrogen Energy 36 (10), $6210 \mathrm{e} 6218$.

Gray NF. Biology of Wastewater Treatment. Imperial College Press. 2004. Available from URL:https://www.researchgate.net/pub lication/278036604_Biology_of_Waste water_Treatment

Greenman, J., G_alvez, A., Giusti, L., Ieropoulos, I., 2009. Electricity from landfill leachate using microbial fuel cells: comparison with a biological aerated filter. Enzyme Microb. Technol. 44 (2), 112e119.

Gregoire, K., Tatinclaux, M., Biffinger, J., Tender, L., Lansing, S., 2013, October. Hybrid anaerobic digester-microbial fuel cell for waste water treatment. In: Meeting Abstracts. The 
Electrochemical Society, p. 225. No. 4. Gregory, K.B., Bond, D.R., Lovley, D.R., 2004. Graphite electrodes as electron donors for anaerobic respiration. Environ. Microbiol. 6 (6), 596e604.

Gude, V.G., Kokabian, B., Gadhamshetty, V., 2013. Beneficial bioelectrochemical systems for energy, water, and biomass production. J. Microb. Biochem. Technol.6, 2.

Ha, P.T., Lee, T.K., Rittmann, B.E., Park, J., Chang, I.S., 2012. Treatment of alcohol distillery wastewater using a bacteroidetes-dominant thermophilic microbial fuel cell. Environ. Sci. Technol. 46 (5), 3022e3030.

Hankin, L. and L. Anagnostaksis, "The use of solid media for detection of enzyme production by fungi," Mycologia, vol. 47, pp. 597-607, 1975.

Heidrich, E.S., Curtis, T.P., Dolfing, J., 2010. Determination of the internal chemical energy of wastewater. Environ. Sci.. \& Technol 45 (2), 827e832.

Hoffmann, R.A., Garcia, M.L., Veskivar, M., Karim, K., Al-Dahhan, M.H., Angenent, L.T., 2008. Effect of shear on performance and microbial ecology of continuously stirred anaerobic digesters treating animal manure. Biotechnol.Bioeng. 100 (1), 38e48.

Ichihashi, O., Hirooka, K., 2012. Removal and recovery of phosphorus as struvite from swine wastewater using microbial fuel cell. Bioresour. Technol. $114,303 \mathrm{e} 307$.

Ieropoulos, I.A., Ledezma, P., Stinchcombe, A., Papaharalabos, G., Melhuish, C., Greenman, J., 2013. Waste to real energy: the first MFC powered mobile phone. Phys. Chem. Chem. Phys. 15 (37), 15312e15316.

Inslee J. Apollo's Fire: Igniting America's Clean Energy Economy. Island Press. 2008: 157.

Kitani O and Hall CW. Biomass Handbook.
Taylor and Francis US. 1989: 256.

Macris, B. J., M. Paspaliari, and D. Kekos, "Production and cross-synergistic action of cellulolytic enzymes from certain fungalmutants grown on cotton and straw," Biotechnology Letters, vol. 7, no. 5, pp. 369-372, 1985.

Mandels, M. and D. Sternberg, "Recent advances in cellulases technology," Journal of Fermentation Technology, vol. 54, no. 4, pp. 267-286, 1976.

Miller, G. L., "Use of dinitrosalicylic acid reagent for determination of reducing sugar," Analytical Chemistry, vol. 31, no. 3, pp. 426-428, 1959.

Moharram, A. M., S. I. I. Abdel-Hafez, and M. A. Abdel-Star, "Cellulolytic activity of fungi isolated from different substrates from the New Valley Governorate, Egypt," Pure Science Engineering, vol. 1, pp. 101-114, 1995.

National Population Commission (2017). Homepage. Available from URL: http://www.population.gov.ng/index.ph $\mathrm{p} / 80$-publications/216-nigeria-spopulation-now-182-million-dg-npopc

Pointing, S. B. "Qualitative methods for the determination of lignocellulolytic enzyme production by tropical fungi," Fungal Diversity, vol. 2, pp. 17-33, 1999.

Proom, H. and B. C. J. G. Knight, "The minimal nutritional requirements of some species in the genus Bacillus," Journal of General Microbiology, vol. 13, no. 3, pp. 474-480, 1955.

Rahman, A., M. F. Begum, M. Rahman, and M. A. Bari, "Isolation and identification of Trichoderma species from different habitats and their use for bioconversion of solid waste," Turk Journal of Biology, vol. 34, pp. 1-12, 2010.

Raper, K. B. and C. Thom, A Manual of the Penicillia, Williams \& Wilkins, 
Baltimore, Md, USA, 1949.

Saddler, J. N., M. K. H. Chan, M. Mes, Hartree, and C. Brevil, "Cellulase production and hydrolysis of pretreated lignocelluloses substrate in biomass conversion technology," in Principles and Practice, M. Moo Young, Ed., Pciqumon Press, 1987.

Satyanarayana T, Bhavdish-Narain $\mathrm{J}$ and Prakash A. Microorganisms in Environmental Management: Microbes and Environment. Springer Publishers, Netherlands. 2012.

Sherief, A. A., A. B. El-Tanash, and N. Atia, "Cellulase production by Aspergillus fumigatus grown on mixed substrate of 12 International Journal of Microbiology rice straw and wheat bran," Research Journal of Microbiology, vol. 5, no. 3, pp. 199211, 2010.

Sridhar, M. K. C. (2013). The Challenge of Waste Management in Nigeria: Recommendations towards a Functional National Policy. National Conference on the Environment. Available from URL: http://tandicebsolutions.com/rokdownl oads/National_Conference_on_the_En vironment/Prof_Sridhar_Abuja_present ation1.pdf

Steph. Beneficial Bacteria: 12 Ways Microbes Help the Environment. Homepage of Momtastic Webecoist. 2017. Available from

URL:http://webecoist.momtastic.com/2 011/09/26/beneficial-bacteria-12-ways- microbes-help-the-

environment/\#Ui0eMCypLJvobdGf.99

Strom, P. F., "Identification of thermophilic bacteria in solidwaste composting," Applied and Environmental Microbiology, vol. 50, no. 4, pp. 906913, 1985.

Tickell J. From the Fryer to the Fuel Tank: The Complete Guide to Using Vegetable Oil as an Alternative Fuel. Biodiesel America. 2000: 53.

Vrieze J. "The littlest farmhands". Science. 2015, 349 (6249): 680-683. Available from

URL:https://www.ncbi.nlm.nih.gov/pu bmed/26273035

Waksman, S. A., Principles of Soil Microbiology, Williams \& Wilkins, Baltimore, Md, USA, 1927.

Wilson, D. B. "Microbial diversity of cellulose hydrolysis," Current Opinion in Microbiology, vol. 14, pp. 259-263, 2011.

Wood, T. M. and K.M. Bhat, "Methods formeasuring cellulose activities," in Methods in Enzymology, W. A. Wood and S. T. Kellogg, Eds., vol. 160, p. 87, Academic Press, New York, NY, USA, 1988.

Wood, T. M. and S. I. McCrae, "Purification and some properties of a $(1 \rightarrow 4)-\beta$-dglucan glucohydrolase associated with the cellulase from the fungus Penicillium funiculosum," Carbohydrate Research, vol. 110, no. 2, pp. 291-303, 1982.

\section{How to cite this article:}

Bhanu Pratap Singh and Pradeep Srivastava. 2020. Microorganisms Coexisting Techniques for Waste Treatment. Int.J.Curr.Microbiol.App.Sci. 9(12): 1371-1397. doi: https://doi.org/10.20546/ijcmas.2020.912.167 